\title{
Determination of Mercury in Ayurvedic Dietary Supplements That Are Not Rasa Shastra Using the Hydra-C Direct Mercury Analyzer
}

\author{
Amir A. Abdalla and Robert E. Smith \\ Total Diet and Pesticide Research Center, U.S. Food and Drug Administration, 11510 W 80th Street, Lenexa, KS 66214, USA \\ Correspondence should be addressed to Robert E. Smith; robert.smith@fda.hhs.gov
}

Received 4 February 2013; Accepted 10 April 2013

Academic Editor: Xiaolin Hou

Copyright (C) 2013 A. A. Abdalla and R. E. Smith. This is an open access article distributed under the Creative Commons Attribution License, which permits unrestricted use, distribution, and reproduction in any medium, provided the original work is properly cited.

Mercury has been determined in Ayurvedic dietary supplements (Trifala, Trifala Guggulu, Turmeric, Mahasudarshan, Yograj, Shatawari, Hingwastika, Shatavari, and Shilajit) by inductively coupled plasma-mass spectrometry (ICP-MS) and direct mercury analysis using the Hydra-C direct mercury analyzer (Teledyne Leeman Labs Hudson, NH, USA). Similar results were obtained from the two methods, but the direct mercury analysis method was much faster and safer and required no microwave digestion (unlike ICP-MS). Levels of mercury ranged from 0.002 to $56 \mu \mathrm{g} / \mathrm{g}$ in samples of dietary supplements. Standard reference materials Ephedra 3240 and tomato leaves that were from the National Institute of Standard and Technology (NIST) and dogfish liver (DOLT3) that was from the Canadian Research Council were analyzed using Hydra-C method. Average mercury recoveries were 102\% (RSD\% 0.0018), $100 \%$ (RSD\% 0.0009), and 101\% (RSD\% 0.0729), respectively. Hydra-C method Limit Of Quantitation was $0.5 \mathrm{ng}$.

\section{Introduction}

Ayurveda is a traditional form of medicine that originated on the Indian subcontinent during the Vedic period and is still widely used by many [1]. These "medicines" can be divided into two broad disciplines: herbal only and rasa shastra, in which metals, including mercury, are added [2]. In a survey of Ayurvedic medicines in the Boston area, 20\% were found to contain lead, mercury, and/or arsenic when analyzed by X-ray fluorescence [3]. The range of mercury found was $28-104000 \mu \mathrm{g} / \mathrm{g}$ [3]. Similar results were found in products obtained over the internet, in which $20 \%$ of all the products contained lead, mercury, and/or arsenic and $40.6 \%$ of the rasa shastra products contained mercury, ranging from 13 to $28 \mathrm{mg} / \mathrm{g}$ [4]. These are over four orders of magnitude greater than the FDA action level for mercury in fish, which is $0.001 \mathrm{mg} / \mathrm{g}$ or $1 \mu \mathrm{g} / \mathrm{g}$ [5]. However, uncontrollable matrix effects make X-ray fluorescence a nonquantitative technique.

There are also metallic-herb preparations called bhasmas, which are used in the rasa shastra discipline [6]. Bhasma means "ash" and is a preparation made from precious metals and their salts [6]. One of the, Siddha Makaradhwaja, was found to contain $85.3 \pm 7.0 \%$ mercury as $\mathrm{HgS}$, with no traces of any other elements [6]. Another mercury-based bhasma, parad, contained $0.018 \pm 0.002 \%(180 \pm 2 \mu \mathrm{g} / \mathrm{g})$ [6]. Several other bhasmas that were not based on mercury still contained much more than $1 \mu \mathrm{g} / \mathrm{g}$, with one (Praval Pishti) containing $627 \pm 20 \mu \mathrm{g} / \mathrm{g}$, when analyzed by flame atomic absorption spectrophotometry [6].

Other dietary supplements have been analyzed by ICPMS for $\mathrm{As}, \mathrm{Pb}, \mathrm{Hg}$, and $\mathrm{Cd}[7,8]$, in which samples were prepared by microwave digestion [9]. This method is laborintensive and has caused extreme safety concerns, including explosions [10]. There is another method based on oxidation, purge and trap, and cold vapor atomic fluorescence spectrometry that does not require digestion or any other sample preparation and it is the basis for US EPA method $7473[11,12]$. It provides an inexpensive, simple, and convenient approach to mercury analysis without any sample pretreatment and without any hazardous chemical waste. Typical analysis times are approximately five min per sample. Solid samples are decomposed by combustion in the presence of $\mathrm{O}_{2}$. The gases produced are carried through a heated tube containing a catalyst, which removes halogens, nitrogen oxides, and 
sulfur oxides. The remaining combustion products, which include $\mathrm{Hg}^{0}$, are swept through a gold amalgamation tube that captures the $\mathrm{Hg}^{0}$ and then releases it as a gaseous bolus into the oxygen carrier gas, which sends it to a direct mercury analysis. The transient signal is measured in series by high and low sensitivity cells. The two peaks are integrated and compared to the best calibration data of the two cells. This provides a wider dynamic range (3-600 ng) than that of a single optical cell analysis. US EPA Method 7473 method was used in the present study to determine $\mathrm{Hg}$ in different samples of Indian dietary supplements that were not rasa shastra. They included Trifala, Trifala Guggulu, Turmeric, Mahasudarshan, Yograj, Shatawari, Hingwastika, Shatavari, and Shilajit. Trifala (or triphala) has been reported to be a $1: 2: 3$ mixture of the three fruits called Harr, Bahera, and Aonla [13]. Trifala guggulu has been reported to be a guggulubased formulation, in which the guggulu is an oleoresin from the Commiphora mukul tree [14]. Turmeric is the rhizome of Curcuma longa and contains the compound curcumin, which has many health benefits [15]. Mahasudarshan is a preparation of tablets containing 45 ingredients, one sample of which was found to have only $0.07 \mu \mathrm{g} / \mathrm{g} \mathrm{Hg}$ [16]. Yograj has been reported to have 28 ingredients and is often sold as a mixture with guggulu [17]. Shatawari (or Shatavari) is made from the root tubers of Asparagus racemosus Linn [18]. Hingwastika has been reported to only contain herbs, one sample of which was found to have $37 \mu \mathrm{g} / \mathrm{g} \mathrm{Hg}$ [19]. Shilajit has been reported to be an exudate from rocks in the Himalaya mountains and it contains mostly paleohumus and organic compounds from fossilized plants [20].

\section{Materials and Methods}

2.1. Reagents and Samples. Samples of Ayurvedic dietary supplements were purchased over the internet. Standard reference materials Ephedra 3240 and tomato leaves were from NIST and dogfish liver (DOLT3) was from the Canadian Research Council. Approximately half of each bottle of dietary supplements sample was placed in a blender and then blended to homogenous composite prior to the analysis. For products provided in tablet form approximately, half of each bottle was manually grounded into homogenous composite. Trace metals grade $30 \% \mathrm{H}_{2} \mathrm{O}_{2}$, concentrated $\mathrm{HCl}, \mathrm{HNO}_{3}$ and concentrated $\mathrm{H}_{2} \mathrm{SO}_{4}$ were purchased from GFS (Powell, $\mathrm{OH}$ ) and used for the digestion. A $1000 \mu \mathrm{g} / \mathrm{mL} \mathrm{Hg}$ standard in $2 \%$ $\mathrm{HNO}_{3}$, from ICP International (Santa Rosa, CA, USA), was used to spike the samples and measure spike recovery.

2.2. Sample Preparation. Microwave digestion of about $0.7 \mathrm{~g}$ of sample was done using Milestone Ultrawave microwave digestion system (Shelton, CT, USA) and quartz tubes. The microwave system contains a large pressurize reaction chamber in which all samples were digested simultaneously. The reaction chamber was prepressurized using $\mathrm{N}_{2}$ gas prior to start the run. Power was 1500 Watts, with a starting temperature of $120^{\circ} \mathrm{C}$ and pressure at $40 \mathrm{bar}$ and then the temperature increased linearly to $230^{\circ} \mathrm{C}$ for $8 \mathrm{~min}$ and then held at $230^{\circ} \mathrm{C}$ for $8 \mathrm{~min}$. The reaction chamber was cooled to $25^{\circ} \mathrm{C}$. After cooling to $25^{\circ} \mathrm{C}$, a final $0.5 \mathrm{~mL}$ of $30 \% \mathrm{H}_{2} \mathrm{O}_{2}$, and $0.5 \mathrm{~mL}$ of $\mathrm{HCl}$ were added to each sample, followed by diluting to $100.0 \mathrm{~mL}$ with deionized water. Acids concentrations in sample digests were approximately $2 \%$ $\mathrm{HNO}_{3}$ and $0.5 \% \mathrm{HCl}$ ( $\mathrm{HCl}$ was used to stabilize $\mathrm{Hg}$ ). ICPMS analysis was done on an Agilent 7700x ICP-MS (Santa Clara, CA, USA). Spiking standards were prepared by adding $\mathrm{Hg}$ from a stock standard solution of $1000 \mu \mathrm{g} / \mathrm{mL} \mathrm{Hg}$ in $2 \%$ $\mathrm{HNO}_{3}$, from ICP International (Santa Rosa, CA, USA) to a flask containing a solution of $5 \%$ nitric acid and $1.0 \% \mathrm{HCl}$ to a final concentration of $500 \mu \mathrm{g} / \mathrm{L}$. The standard was added to the solid samples in the sample boat. Iridium was used as the internal standard. The percent recoveries of samples spiked with $\mathrm{Hg}$ are listed in Table 1. Isotopes of $\mathrm{Hg}$ and internal standard for ICP-MS analysis are listed in Table 2. ICP-MS instrument was calibrated using NIST traceable standards. The calibration has a correlation coefficient $\left(r^{2}\right)$ value of $>0.995$.

2.3. Instrumental Analysis. For the determination of $\mathrm{Hg}$, a Hydra-C mercury analyzer, model IIc was used (Teledyne Leeman Labs Hudson, NH, USA) without any sample digestion. Approximately $100 \mathrm{mg}$ of each dietary supplement sample (60-85 mg National Institute of Standard and Technology (NIST) Standard Reference material (SRM) 3240 (Ephedra sinica Stapf Aerial Parts), tomato leaves, and dogfish liver (Gaithersburg, MD, USA) was weighed directly into a nickel boat, and then the nickel boat was introduced into a decomposition furnace. Percent recoveries were measured in duplicate. The thermal decomposition technique described in EPA method 7473 and ASTM method 6722-01 was used for the analysis. The Standard Operating Conditions for Direct Mercury Analysis are listed in Table 3.

Prior to sample analysis Hydra-C instrument was calibrated using NIST traceable standards. Calibration was completed using aqueous standards prepared in $1.0 \% \mathrm{HNO}_{3}$. Instrument linearity was established across two separate ranges; a low range ( $0 \mathrm{ng}$ to $30 \mathrm{ng}$ ) and high range ( $40 \mathrm{ng}$ to $600 \mathrm{ng}$ ). The high calibration range has a correlation coefficient $\left(r^{2}\right)$ value of 0.9992 and the low calibration range has an $r^{2}$ value of 0.9996 . Six dietary supplements samples were fortified with approximately $0.10 \mathrm{ng} / \mathrm{g} \mathrm{Hg}$ to check for matrix effects. The percent recoveries of samples spiked with $\mathrm{Hg}$ are listed in Table 1.

\section{Results and Discussion}

The two methods gave very similar results for the ten samples analyzed, as shown in Table 4. This is much like the agreement between results that was seen in red yeast rice [21]. Levels of mercury ranged from 0.002 to $56 \mu \mathrm{g} / \mathrm{g}$. Even though the two methods found different amounts in the sample containing the most $\mathrm{Hg}$, both methods can easily distinguish between samples that are below or above the $1 \mu \mathrm{g} / \mathrm{g}$ action level. It should be noted that the sample containing the most $\mathrm{Hg}$ had to be diluted by adding some of the stock standard solution to the solid sample, which can cause errors due to sample inhomogeneity. As reported by others [19], it is 
TABLE 1: Percent recoveries of Hg spikes by ICP-MS and Hydra C.

\begin{tabular}{lccc}
\hline Item & Name & $\begin{array}{c}\text { ICP-MS percent } \\
\text { recovery }\end{array}$ & $\begin{array}{c}\text { Hydra C percent } \\
\text { recovery }\end{array}$ \\
\hline Tu-S1 & Turmeric & $106 \%$ & $110 \%$ \\
Shv-S1 & Shatawari & $112 \%$ & $112 \%$ \\
Shil-S1 & Shilajita & $93 \%$ & $106 \%$ \\
\hline
\end{tabular}

TABLE 2: Isotopes of $\mathrm{Hg}$ for ICP-MS, used with an iridium internal standard.

\begin{tabular}{lcc}
\hline Element & Analyte mass & Internal standard mass \\
\hline $\mathrm{Hg}$ & 201 & 193 \\
$\mathrm{Hg}$ & 202 & 193 \\
\hline
\end{tabular}

TABLE 3: Standard operating conditions for Hydra-C direct mercury analyzer.

\begin{tabular}{lcc}
\hline Parameter & Time $(\mathrm{s})$ & Temp $\left({ }^{\circ} \mathrm{C}\right)$ \\
\hline Dry & 50 & 250 \\
Decomposition & 200 & 600 \\
Catalyst & 60 & 600 \\
Amalgam & 30 & 600 \\
Integration & 60 & N.A. \\
Oxygen flow & $300 \mathrm{ml} / \mathrm{min}$ & N.A. \\
\hline
\end{tabular}

TABle 4: Comparison between Hydra C and ICP-MS results, measured in duplicate.

\begin{tabular}{lcc}
\hline Item & Hydra-C $(\mu \mathrm{g} / \mathrm{g})$ & ICP-MS $(\mu \mathrm{g} / \mathrm{g})$ \\
\hline Trifala Guggulu & 5.109 & 4.345 \\
Trifala & 0.188 & 0.182 \\
Turmeric & 0.006 & 0.004 \\
Mahasudarshan & 9.519 & 10.644 \\
Yograj & 8.233 & 9.766 \\
Shatawari & 0.013 & 0.011 \\
Hingwastika & 38.959 & 56.503 \\
Shatavari & 0.007 & 0.006 \\
Triphala & 0.002 & 0.005 \\
Shilajita & 0.760 & 0.686 \\
\hline
\end{tabular}

Trifala and Triphala are two different samples of what may be the same dietary supplement.

TABLE 5: Analysis of standard reference materials (SRMs) by the Hydra C for Hg.

\begin{tabular}{lcc}
\hline QC Standards & $\begin{array}{c}\text { Certified Hg content } \\
(\mu \mathrm{g} / \mathrm{g})\end{array}$ & \% recovery \\
\hline SRM 3240 ephedra & $0.0167 \pm 0.0005$ & $101 \pm 10$ \\
SRM tomato leaves & $0.0340 \pm 0.004$ & $100 \pm 2$ \\
SRM DOLT 3 dogfish liver & $3.37 \pm 0.14$ & $101 \pm 3$ \\
\hline
\end{tabular}

important to dilute the sample before analyzing it, to prevent contaminating the instrument with excess $\mathrm{Hg}$.

As a test of accuracy, Hydra $\mathrm{C}$ method found the amounts of $\mathrm{Hg}$ in standard reference materials (Table 5), and spiked
TABLE 6: Comparison and practical considerations for using Hydra $\mathrm{C}$ versus ICP-MS.

\begin{tabular}{|c|c|}
\hline Hydra C & ICP-MS \\
\hline $\begin{array}{l}\text { No Sample digestion } \\
\text { (lower cost per analysis) }\end{array}$ & Need sample digestion \\
\hline $\begin{array}{l}\text { No Hazardous chemical or } \\
\text { waste }\end{array}$ & Hazardous chemical or waste \\
\hline $\begin{array}{l}\text { All of the } \mathrm{Hg} \text { in each sample is } \\
\text { collected on the amalgam prior } \\
\text { to analysis }\end{array}$ & $\begin{array}{l}\text { Hg can be lost from aqueous } \\
\text { samples during digestion }\end{array}$ \\
\hline About 5 minutes/sample & About $30 \mathrm{~min} / \mathrm{sample}$ \\
\hline $\begin{array}{l}\text { All the Hg gets to the detector, } \\
\text { so sensitivity is good. }\end{array}$ & $\begin{array}{l}\text { ICP-MS system must provide } \\
\text { very high sensitivity to } \\
\text { compensate for Hg low degree } \\
\text { of ionization in the plasma }\end{array}$ \\
\hline $\begin{array}{l}\text { Decrease the chance of } \\
\text { contamination }\end{array}$ & $\begin{array}{l}\text { Chance of contamination } \\
\text { during the digestion process }\end{array}$ \\
\hline $\begin{array}{l}\text { No carry over effect or loss of } \\
\text { sample (no tubing required) }\end{array}$ & $\begin{array}{l}\text { Significant carry over effect and } \\
\text { loss of sample via tubing. }\end{array}$ \\
\hline
\end{tabular}

samples (Table 1) that were close to the expected values. ICP-MS method found the proper amounts of $\mathrm{Hg}$ in spiked samples (Table 1). Therefore, it can be concluded that the much faster and safer method using the Hydra C can provide similar accuracy as the ICP-MS method that requires microwave digestion of the samples. Moreover, four of the ten samples had much more than $1 \mu \mathrm{g} / \mathrm{g}$ of $\mathrm{Hg}$. A comparison and practical considerations for using Hydra $\mathrm{C}$ versus ICPMS technique for mercury analysis are listed in Table 6.

\section{Disclosure}

This work should not be taken as reflecting FDA policy or regulations.

\section{References}

[1] N. J. Gogtay, H. A. Bhatt, S. S. Dalvi, and N. A. Kshirsagar, "The use and safety of non-allopathic Indian medicines," Drug Safety, vol. 25, no. 14, pp. 1005-1019, 2002.

[2] A. D. Satpute, Rasa Ratna Samuchaya of Vagbhatta, trans, Chaukhamba Sanskrit Pratishtana, Varanasi, India, 2003.

[3] R. B. Saper, S. N. Kales, J. Paquin et al., "Heavy metal content of Ayurvedic herbal medicine products," The Journal of the American Medical Association, vol. 292, no. 23, pp. 2868-2873, 2004.

[4] R. B. Saper, R. S. Phillips, A. Sehgal et al., "Lead, mercury, and arsenic in US- and Indian-manufactured Ayurvedic medicines sold via the internet," The Journal of the American Medical Association, vol. 300, no. 8, pp. 915-923, 2008.

[5] United States Food and Drug Administration, Guidance for Industry: Action Levels for Poisonous or Deleterious Substances in Human Food and Animal Feed, United States Food and Drug Administration, Springfield, Va, USA, 2000.

[6] A. Kumar, A. G. C. Nair, A. V. R. Reddy, and A. N. Garg, "Bhasmas: unique Ayurvedic metallic-herbal preparations, chemical characterization," Biological Trace Element Research, vol. 109, no. 3, pp. 231-254, 2006. 
[7] S. P. Dolan, D. A. Nortrup, P. M. Bolger, and S. G. Capar, "Analysis of dietary supplements for arsenic, cadmium, mercury, and lead using inductively coupled plasma mass spectrometry," Journal of Agricultural and Food Chemistry, vol. 51, no. 5, pp. 1307-1312, 2003.

[8] R. N. Rao and M. V. N. K. Talluri, "An overview of recent applications of inductively coupled plasma-mass spectrometry (ICP-MS) in determination of inorganic impurities in drugs and pharmaceuticals," Journal of Pharmaceutical and Biomedical Analysis, vol. 43, no. 1, pp. 1-13, 2007.

[9] G. Qiu, X. Feng, P. Li et al., "Methylmercury accumulation in rice (Oryza sativa L.) grown at abandoned mercury mines in Guizhou, China," Journal of Agricultural and Food Chemistry, vol. 56, no. 7, pp. 2465-2468, 2008.

[10] C. Smith, "Microwave digestion of foods using the Milestone Q20 quartz rotor set," LIB, 4458, 2010, http://inside. fda.gov:9003/downloads/PolicyProcedures/Laboratories /LaboratoryInformationBulletins/UCM224868.pdf.

[11] United States Environmental Protection Agency, Method 1631, Revision E: Mercury in Water by Oxidation, Purge and Trap, and Cold Vapor Atomic Fluorescence Spectrometry, U.S. EPA, Office of Water, Washington, DC, USA, 2002.

[12] D. L. Pfeil and M. L. Bruce, "Automated determination of mercury by cold vapor atomic fluorescence with gold amalgamation," The American Laboratory, vol. 33, no. 18, pp. 26-30, 2001.

[13] J. B. Tomar, S. K. Bishnoi, and K. K. Saini, "Healing the traditional way: ethno-medicinal formulations used by the tribes of Jharkhand, India," International Journal of Medicinal and Aromatic Plants, vol. 2, pp. 97-105, 2012.

[14] V. N. Sumantran, A. A. Kulkarni, A. Harsulkar et al., "Hyaluronidase and collagenase inhibitory activities of the herbal formulation Triphala guggulu," Journal of Biosciences, vol. 32, no. 4, pp. 755-761, 2007.

[15] R. K. Maheshwari, A. K. Singh, J. Gaddipati, and R. C. Srimal, "Multiple biological activities of curcumin: a short review," Life Sciences, vol. 78, no. 18, pp. 2081-2087, 2006.

[16] G. S. Lavekar, B. Ravishankar, S. V. Rao, V. J. Shukla, B. K. Ashok, and S. N. Gaidhani, "Safety study on a selected Ayurvedic formulation: Mahasudarshan Ghan Vati," Indian Drugs, vol. 46, pp. 850-859, 2009.

[17] A. K. Meena, A. Sachan, R. Kaur et al., "Quality assessment of different variants of Yogaraj Guggulu," International Journal of Pharmaceutical Quality Assurance, vol. 2, pp. 35-37, 2010.

[18] V. Madhavan, R. D. Tijare, R. Mythreyi, M. R. Gurudeva, and S. N. Yoganarasimhan, "Pharmacognostical studies on the root tubers of Asparagus gonoclados Baker-Alternate source for the Ayurvedic drug Shatavari," Indian Journal of Natural Products and Resources, vol. 1, no. 1, pp. 57-62, 2010.

[19] I. Jayawardene, R. Saper, N. Lupoli, A. Sehgal, R. O. Wright, and C. Amarasiriwardena, "Determination of in vitro bioaccessibility of $\mathrm{Pb}, \mathrm{As}, \mathrm{Cd}$ and $\mathrm{Hg}$ in selected traditional Indian medicines," Journal of Analytical Atomic Spectrometry, vol. 25, no. 8, pp. 1275-1282, 2010.

[20] S. P. Agarwal, R. Khanna, R. Karmarkar, M. K. Anwer, and R. K. Khar, "Shilajit: a review," Phytotherapy Research, vol. 21, no. 5, pp. 401-405, 2007.

[21] C. C. Smith, A. M. Abdalla, and R. E. Smith, "Determination of mercury and other metals in red yeast rice," Journal of Natural Products, vol. 2, no. 2, pp. 114-117, 2012. 

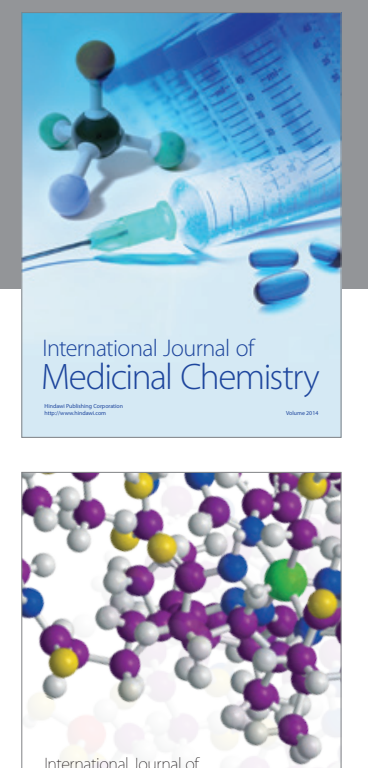

\section{Carbohydrate} Chemistry

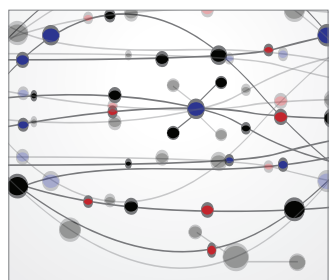

The Scientific World Journal
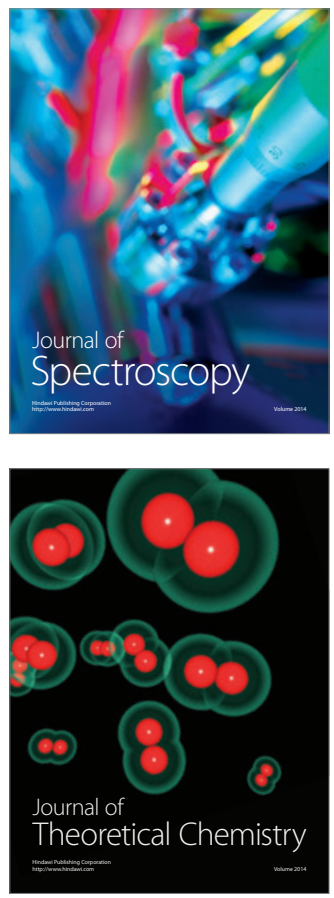
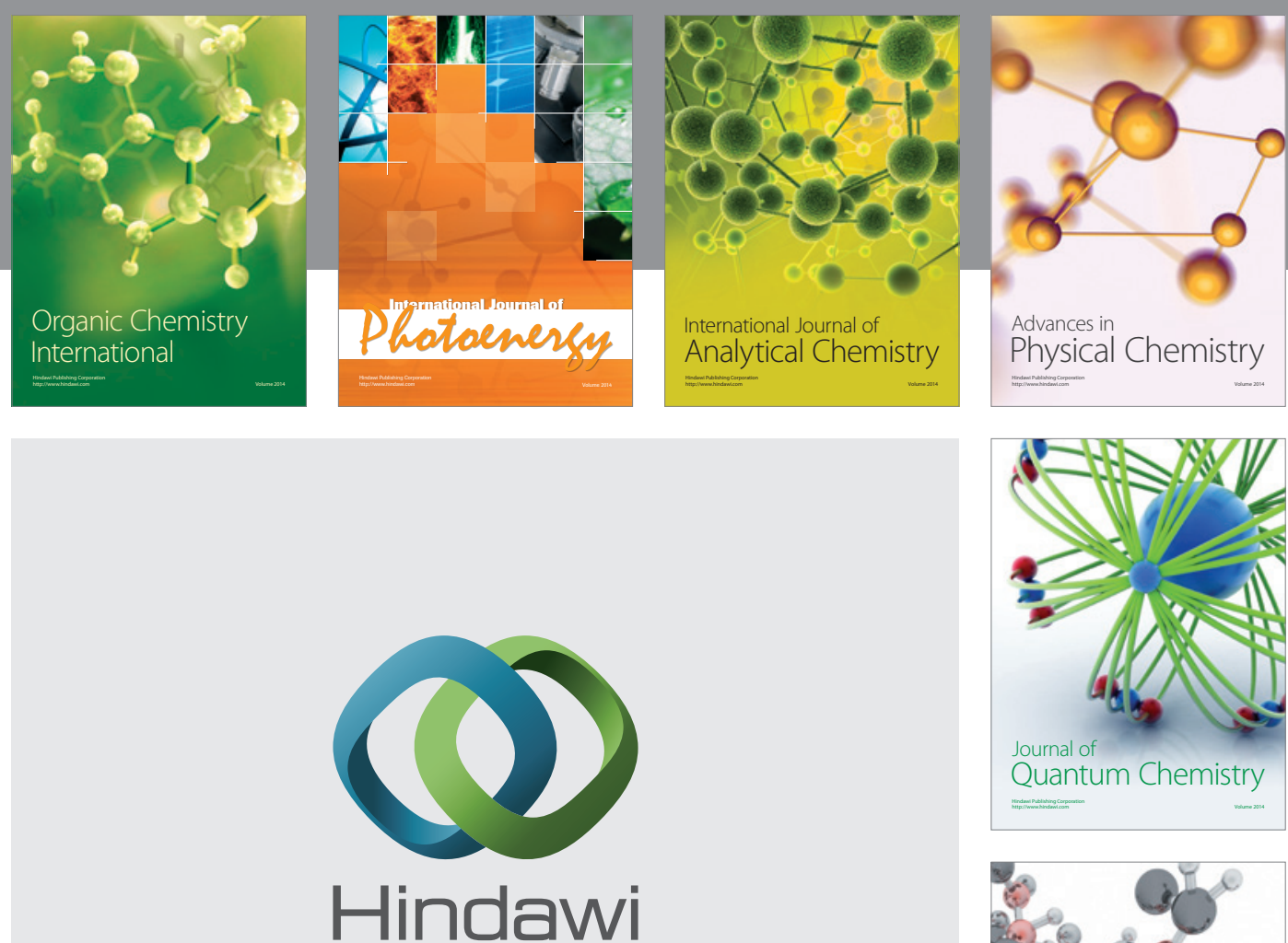

Submit your manuscripts at

http://www.hindawi.com

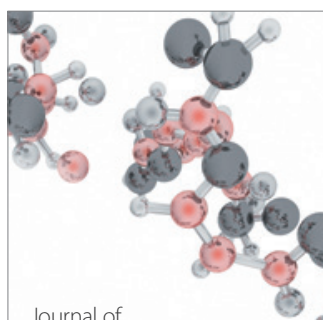

Analytical Methods

in Chemistry

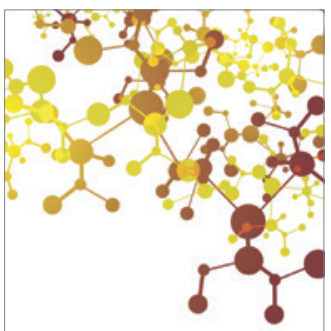

Journal of

Applied Chemistry

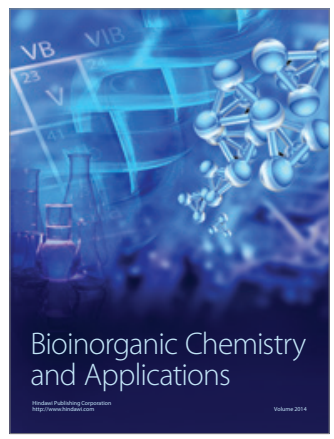

Inorganic Chemistry
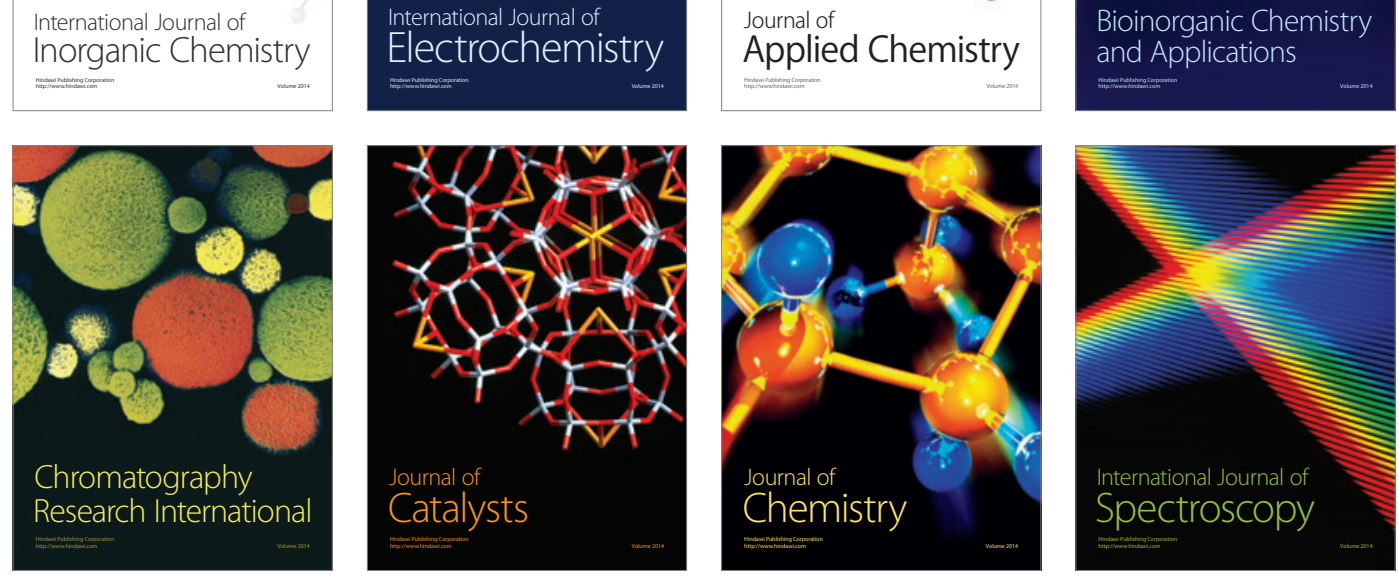